\title{
Contributions of women's welfare associations in facing the marriage of underage girls
}

\section{Shadia Rabie Zaky}

Associate Professor of Community Organization

Higher Institute of Social Work in Cairo

\section{Moustafa Mohamed Moawad}

Associate Professor of Community Organization

Higher Institute of Social Work in Cairo 



\section{Abstract:}

This study belongs to the pattern of descriptive and analytical studies, with an analysis of the quantitative and qualitative reasons that led to the spread of early marriage for girls and an analysis of the quantitative and qualitative relationship between early marriage for girls and their social standards. The study is based on the social sample survey method represented in a simple random sample of underage married girls who obtain social and health care services from women welfare associations. The study relied on collecting its data on a questionnaire regarding the contributions of women's welfare associations in reducing marriage for underage girls (Applicable to minor married girls). The most important result of the study confirmed the existence of a statistically significant correlation between marriage of underage girls and their social standards in terms of income, education, and work. The study recommends supporting married girls by providing them with gynecological health services and using community dialogue to work on bridging the legal gaps that allow bypassing the law of early marriage.

\section{Keywords:}

Women's welfare associations - marriage for underage girls

\section{Introduction:}

Underage marriage violates underage girls' rights and has widespread and long-term repercussions on them and on their children later. (Parsons, Edmeades, Aslihan, Petroni, Sexton, and Wodon, 2015, P. 12)

In addition, those girls suffer from health problems and a decrease in the level of education and training, as well as their suffering from the effects of early pregnancy and childbirth. (Gaston and Misunas, 2019, 45)

There are many dimensions to the problem of child marriage: social, legal, and human rights dimensions. Efforts have been made by social reformers to raise the age of marriage for girls; however, the problem remains largely unsolved. The efforts of women's associations focused on how to support the patriarchal social structure to stop the practice of underage girls' marriage because of culture and traditions that suppress women's life experiences. The marriage of minor girls in particular negatively affects their gynecological health, deprives them of the right to education and development, and makes them live the rest of their lives in humiliation and indignity. Besides, young girls are discriminated against by law, culture and society against their peers on the basis of gender and age when they are married before reaching the legal age. (Sajady, 2002) 
Although the legal age of adulthood and the age of marriage is usually designated at age 18, both vary across countries, and therefore the age of marriage may be older or younger in a given country. (Gaston and Misunas, 2019, 45)

Undoubtedly, there are great efforts exerted by international civil society organizations to curb this phenomenon. Given the United Nations Charter in promoting universal respect for and observance of human rights and fundamental freedoms for all without distinction as to race, sex, language, or religion, that Article 16 of the Universal Declaration of Human Rights states that "when men and women attain puberty, they have the right to marry and establish Family, without any limitation due to race, nationality or religion. They are equal in rights upon marriage, during marriage and at its dissolution". Recalling further, the United Nations General Assembly declared by Resolution 843 of December 17, 1954 that some old customs, laws and customs related to marriage and the family are inconsistent with the principles set forth in the United Nations Charter and in the Universal Declaration of Human Rights, and reaffirming that all states to take all appropriate measures to repeal such old customs and laws by ensuring complete freedom to choose a husband and by completely abolishing child marriages and sermons before puberty, by determining appropriate penalties when necessary, and by creating a civil or non-civil registry in which all marriage contracts are registered (United Nations,1964).

As for Egypt, Official statistics indicate that 117 thousand children in the age group from 10 to 17 are married or previously married. The Upper Egypt governorates recorded the highest rate of child marriage and divorce, while Egypt's border governorates - the Red Sea, Sinai, Marsa Matrouh and Aswan - recorded the lowest percentage in child marriage (Central Agency for Public Mobilization and Statistics, 2017).

The causes of underage girls marriages are attributed to poverty, bride dowry, cultural traditions, religious and social pressures, regional customs, fear of the underage girls to stay unmarried into adulthood, illiteracy, and the perceived inability of women to work for money. Such underage girls' marriage includes civil cohabitation and court approval of early marriages because of teenage pregnancy (Sharon and Susan, 2005, pp. 607-620).

Even where the age is set at 18 years, cultural traditions may override legislation and many jurisdictions permit earlier marriage with parental consent or in special circumstances, such as teenage pregnancy (Nour, 2009, $51)$. 
Furthermore, there is little research on problems of children resulting from underage girls' marriages, but effects on boys include being ill-prepared for certain responsibilities such as providing for the family, early fatherhood, and a lack of access to education and career opportunities (Gaston and Misunas, 2019, 45).

Referring to studies that deal with underage marriage, a study (Muthengi, 2010) confirmed that early marriage is defined as marriage of girls below the age of 18 years, and it is a human rights violation according to many international standards and national laws. It is often driven by poverty and supported by social norms that foster gender inequalities. Early marriage is associated with numerous adverse effects on young girls, including health risks, early childbearing and reduced education. Study finds that early marriage is strongly associated with reduced educational attainment. Results show that the association between the timing of marriage and economic resources is partially mediated by education, and primary school completion is strongly associated with increased access to cash income and household wealth. I also find that involvement in health decisions is increased by education, cash income, delayed marriage, and household wealth. As for the study (Kimball, 2011), this study suggests that marriage before the age of 18 is a serious development and humanitarian issue with broad-reaching ramifications throughout societies. They found that female education has a negative relationship with the rates of child marriage occurrence. As female secondary enrollment increases, it positively affects the rates of child marriage. Moreover, this study suggests that democratization is not necessarily an effective way to combat child marriage in developing countries. This study presents a female empowerment framework to enhance education and reduce incidences of child marriage. This framework comprises raising awareness, improving institutions, and eventually gaining social acceptance. The objective of this study (Liu, 2013) is to explore the hypotheses that younger maternal age of marriage, younger maternal age at child birth and family member's involvement in labor migration are associated with increased malaria risk among their children under 18 years old. The results provide new insights of potential risk factors of child malaria and support the hypotheses that mother's early marriage timing, younger age at child birth and family member's involvement in labor migration correlate positively to increased malaria risk among children and adolescents in the Peruvian Amazon. This study uses (Lackovich-Van Gorp, 2014) Positive Deviance to elaborate on child marriage. Marriage by abduction occurs among the poorest $10 \%$ of the "Sidama" population and entails the kidnapping of girls between the ages of 10 and 14 for forced genital circumcision, rape and marriage. This study, 
which entailed an examination of the evolution of marriage norms among the "Sidama" as well as an analysis of the underpinnings of marriage by abduction, discovered that some community members practice behaviors and strategies that can prevent child marriage by abduction. Study (Bakhtibekova, 2014) aimed (1) to draw attention to the issue of early marriage among girls in Tajikistan and (2) to contribute to the scholarly discussion on early marriage and on gender and family dynamics in Tajikistan. Based on the findings, it is recommended that more research needs to be conducted to discuss the phenomenon of early girls' marriage in Tajikistan. Further legal, political and social changes are necessary to provide a safety net for women married at an early age but divorced or abandoned later. Although bringing changes to the marriage values might be a challenging task, it is hoped that this research and others similar to this one will demonstrate the importance of the issue and will result in appropriate attention and an effective policy response. This study (Adjei, 2015) examined the cycle of poverty among women from the Kassena-Nankana district in the Upper East region of Ghana. Negative practices such as early marriage and the challenges of underdevelopment and poverty, and north-south migration are revealed in this study and have served as constraints to women's development. In this thesis, twenty-five individual interviews were conducted, together with 2 focus group discussions. The results showed evidence of early marriage negative effects on education, household finances, and health care. Based on the findings collected, recommendations are made for advocating the eradication of early marriage practices, improving girl-child educational scholarships, and improving skilled-based programs for women. More importantly, greater enforcement of the law should be placed on distasteful traditional practices that create harmful outcomes for women's development.

The study examined "Gaston, Colleen Murray; Misunas, Christina; Cappa, 2019" child marriage among boys, where she indicated that this practice is becoming less common compared to 25 years ago. Countries with the highest prevalence of child marriage among boys vary geographically and differ from countries where this practice is most common among girls. As for the study (Waters, 2019), she indicated that the highest rates of girls entering into early marriage are in rural areas and among indigenous populations. We must understand the historical background of an area when addressing an issue as socially complex as child marriage. Moreover, the presence of a particularly oppressive labor system contributed to higher rates of girls getting married before the age of fifteen. 
As mentioned above, we find civilian society organizations, including women's welfare societies, play important contributions aimed at combating early and forced marriage for girls, and eliminating it in the current generation of girls. This is done by adopting regional strategies to combat child early and forced marriage for girls, as well as working to enhance the impact side by side with regional, national and global bodies, supporting women's movements at the local and global levels, and expanding the dissemination and participation of applied strategies that are successful in combating the issue of underage marriage for girls. Furthermore, it aims to target the widespread media to display positive images in the field of combating and reducing early and forced marriage (Boender, 2015, p.3).

Based on that, the profession of social work in general and the method of organizing society in particular are concerned with the issue of child marriage as it receives the attention of the community due to the existence of differences between the current law and the state's orientations and community activities on the one hand, and between reality and its hatred on the other hand because of its risks and health consequences. As child marriage causes physical and psychological health problems among married girls at an early age, it threatens community members and affects development plans in society, which prompted researchers to study this phenomenon, learn about it and develop solutions to it.

\section{Study problem:}

Undoubtedly, marriage of children, especially girls under 18 years, is considered a violation of the law of children and civil conditions, and it also exposes the health, safety and morals of the child to many risks. This type of early marriage is considered a crime in which the girl loses her human rights and human dignity leading her to an abyss and a vicious circle that perpetuates poverty and ignorance, and consequently turns the girl into an inhumane episode of ill health, education, social and economic disorder, which affects the future of society.

This marriage also creates social problems for the girl, as it causes her to bear greater responsibilities which may lead to dropping out of her education and depriving her of it. This marriage also leads to the girl's inability to organize a family and plan a stable life; moreover, marriage at an early age may be one of the most important reasons for divorce. There is a relationship between early marriage and divorce, and the marriage of young girls may lead to violence against them, which was confirmed by previous research and studies mentioned in the study. The results of early marriage for girls are not limited to physical violence only, but they extend to many forms, including carrying the burdens of hard work and frequent childbearing and denying their participation in family decision-making. 
Hence, the current study sought to reveal the reality of early marriage for girls, as it tries to shed light on the reasons for this phenomenon because it has a profound impact on society and on achieving the goals of sustainable development. Thus, the objective of the current study is crystallized to answer the following main question: "What is the contribution of women's welfare associations in facing the marriage of underage girls?"

\section{Theoretical premises of the study:" general systems theory":}

General systems theory is the most used theory in the field of social work. Most models of practice in social work use concepts drawn from the general pattern theory. For example, the "feedback system", "client system" and "helping system" have become constant and dominant concepts in the field of social work. In addition, the general theory as a theoretical framework represents many of the practice models currently in use, and in fact, family therapy approaches are based on models based mainly on the general format theory concepts due to the fact that these approaches deal with the family, which in turn are clearer social patterns (Rodway, 1986, p. 515).

-The hypothesis underlying the general systems theory:

The general systems theory refers to two main directions: the analytical direction, where the nature of work with one system has certain characteristics that govern it. It also identifies the nature of the relationships between parts of that system, and then move to another pattern on another level to get to know if it has the same characteristics and features. Using the analytical approach, it is possible to test a set of hypotheses and come up with a new theory. The overall trend is different as there is an attempt to find a general model. Instead of focusing on only one level, several levels are dealt with in different formats at the same time and try to codify them into a unified theoretical model capable of describing them separately as well as describing them together (Hearn, 1969, p. 2).

\section{Benefits from the "general systems theory" in this study:}

Thus, it is possible through this theory to highlight the complex human relations network, in which the contributions of the individual shrink according to his/her contributions and location, which may contribute to high rates of underage marriage for girls in society. Researchers can assist women's welfare associations in interpreting and understanding social problems, including the issue of underage marriage on an interconnected basis and not in isolation from the environment and interactions surrounding it.

Here, the contributions of women's welfare societies can be interpreted according to this study at the level of macro and micro societies and interactions as a structure that consists of buildings and sub-formats and performs important functions as it is affected by the rest of the society and its 
systems (dependent on some of them and complement each other to contribute to facing four problems: adaptation, goal achievement, integration, and stress reduction).

Child marriage is a result of the characteristics and functions of the social system and the independent act unaffected by the pattern is the rare and non-social (i.e. environment). The independent unit is the social system, (i.e. society), and it consists of approved sub-formats (mutual influence and influence between them and between them). When there is a cross between the social arrangements (problems resulting from early marriage for girls), the social systems tends to balance by helping the rest of the subsystems.

\section{Research Goals:}

The study seeks to achieve the following objectives:

a) Define the Contributions of women's welfare associations to reduce the phenomenon of early marriage for girls.

b) Reach a set of proposals that contribute to helping women's welfare associations on facing the phenomenon of underage girl's marriage.

c) Determine the nature and type of relationship between early marriage for girls and their social characteristics in terms of income, education, and work.

d) Determine the nature of the variance between underage girls according to the difference in some social variables: education, age, work, number of family members, and income.

\section{Study hypotheses:}

The objectives of the study are achieved by answering the following research hypotheses:

a) There is a significant statistical relationship at the level of significance $(0.05 \geq \alpha)$ between early marriage for girls and their social characteristics in terms of family income level, education, work, and number of family members.

b) There are statistically significant differences at the level of significance $(0.05 \geq \alpha)$ between underage girls and some social variables (e.g. education, age, work, number of family members, family income level).

\section{The concepts:}

Contributions: "Is an organized pattern of norms with regard to the behavior of an individual or a group or an institution with a particular function in the community," or it is "the function of the individual or a group or an institution in the community and their contributions in a social group or position" (Zahran, 2000, p.164). 
Women's welfare associations: These are social units or human gatherings that are intentionally built to achieve certain objectives. These objectives constitute the desired image that can be achieved by the organization, which represents a purposeful tool towards woman" (Etziono, 1964, p.1).

\section{Operational definition of the concept "Contributions of women's} welfare associations": A set of goals that represent contributions or roles that are performed by some social specialized non-governmental units in the field of caring for female minors within society and are represented in: help in knowing and facing the problems arising from early marriage, direct them to family medical centers to treat underage genital problems resulting from early marriage, provide family counseling on how to overcome family disputes with the husband, encourage community institutions to satisfy the needs of married minors, help the minor wife to obtain her lost rights as a result of her early marriage, and provide financial and in-kind assistance to the minor girl to provide for her essential needs.

Marriage for underage girls: Young girls' marriage is defined as a marriage of a girl before the age of 18 and refers to both formal marriages and informal unions in which children under the age of 18 live with a partner as if married. Child marriage disproportionately affects girls especially. (UNICEF, 2000)

The marriage of minor girls may be formal or informal, with the vast majority being between a girl and a man who is older than her (Sen Nag, 2017, 89).

- Operational definition of the concept of marriage for underage girls according to this study: "A group of females who got married under the legal age (less than 18 years old) through an unconfirmed marriage contract, with the knowledge of her family, and gave birth to a child, and this girl suffers from some health and social problems as a result of this marriage, and she receives health and social care services from the Women's Welfare Associations".

\section{Methodology:}

-Study type: This study belongs to the pattern of descriptive studies, with a view analytical quantitative and qualitative about the reasons that led to the spread of early marriage among girls, as well as analytical quantitative and qualitative relationship between early marriage for girls and their social characteristics. 
-Study Approach: The study is based on the sample social survey method represented in a simple random sample of underage married girls, who obtain social and health care services from women welfare associations.

\section{Tools:}

The study was based on one tool: A questionnaire regarding the contributions of women's welfare associations in reducing marriage for underage girls (Applicable to minor married girls).

\section{Design of the study questionnaire:}

The study relied on a questionnaire designed using the following steps:

a) Examination of the tools of many other studies related to the subject of the questionnaire, and that includes (Liu, 2013), (Bakhtibekova, 2014), (Adjei, 2015), (Muthengi, 2010), (Boender, 2015, p.3), (Kimball,2011), (Waters, 2019).

b) Determining the questionnaire phrases and how they relate to the index measured. The questionnaire was divided into four indicators: a) social and health characteristics of marriage for underage girls, b) the reasons that led to the spread of early marriage among girls, c) contributions of associations to reduce the phenomenon of early marriage for underage girls, and d) proposals that contribute to helping associations in facing the phenomenon of underage girl's marriage.

c) Specifying the length of the paragraphs of the questionnaire: the questionnaire was constructed and divided into categories so that the results of the study could be reached using the arithmetic mean, where the data was encoded and entered into the computer. To determine the length of the triple questionnaire cells (minimum and upper limits), the range was calculated as follows: the largest value - the lowest value $(3-1=2)$ divided by the number of cells of the questionnaire which obtained the corrected cell length $(2 / 3=0.67)$. This value was then added to the lowest value in the questionnaire or the beginning of the questionnaire, which determined the upper limit of this cell. Thus, cell length is as follows:

\section{Table (1) Questionnaire Levels:}

\begin{tabular}{||l||l|}
\hline \hline If the average value of a phrase or dimension varies between 1 and 1.67 & Low level \\
\hline \hline If the average value of a phrase or dimension varies between 1.67 and 2.35 & Mid-level \\
\hline \hline If the average value of a phrase or dimension varies between 2.35 and 3.0 & High level \\
\hline
\end{tabular}

d) Statistical honesty: The study relied on ensuring the statistical validity of the questionnaire through the method of retesting. The questionnaire was applied to a sample of (30) individuals then re-applied to the same sample after fifteen days. The strength in the reliability of the questionnaire phrases (alpha- Kronbach) was calculated using the SPSS program. The 
value of the Alpha parameter for the questionnaire phrases is (0.722), which is an acceptable value. Thus, confirming the validity and consistency of the questionnaire paragraphs and the suitability of the questionnaire for application to the basic study sample.

\section{Sample:}

The study tools were applied to a simple random sample representing the spatial domain for it in NGOs working in the field of women's care, and whose scope of work represents the poor and slum areas of Cairo Governorate. This is due to the widespread phenomenon of child marriage in these regions. As for the human sphere, it is determined in a simple random sample of underage married girls, whose percentage reached (10\%) of the total girls who receive social care services from NGOs. The following table shows the study sample as follows:

\section{Table (2) illustrates the sample framework for the study}

\begin{tabular}{||c||c||c||c||}
\hline Sr & Name of organization & $\begin{array}{c}\text { The number of underage } \\
\text { married girls in the } \\
\text { association }\end{array}$ & $\begin{array}{c}\text { A random sample of (10\%) } \\
\text { of the total girls in the study } \\
\text { population. }\end{array}$ \\
\hline \hline 1 & $\begin{array}{l}\text { alkhalil Ibrahim Society for } \\
\text { Community Development }\end{array}$ & 181 & 18 \\
\hline \hline 2 & $\begin{array}{l}\text { Islamic Charitable } \\
\text { Association for Community } \\
\text { Development }\end{array}$ & 142 & 14 \\
\hline \hline 3 & $\begin{array}{l}\text { Mothers and Children Care } \\
\text { Association }\end{array}$ & 257 & 26 \\
\hline \hline 4 & $\begin{array}{l}\text { Women and Child } \\
\text { Protection Association }\end{array}$ & 294 & 29 \\
\hline \hline & Total & 874 & 87 \\
\hline
\end{tabular}

Through the previous table, the study sample is determined as follows:

1- A random sample of four associations of NGOs working in the field of women's care.

2- A random sample of underage married girls with the total number of 87.

The determinants of the study: The results of this study are determined by the degree of reliability of the tool and its stability, as well as the objectivity of the respondents.

\section{Statistical Analysis Methods:}

Statistical processes were carried out using the SPSS.V. 20.0 software, specifically the statistical package for social sciences. The following statistical methods were applied:

a) Using the "Alpha Kronbach" coefficient, through which the discrimination coefficient for each question is calculated. The question with weak or negative discriminant coefficient is eliminated as the Alpha Cronbach coefficient expresses the degree of internal consistency of the questionnaire. 
b) Calculating the range to determine the length of the questionnaire cells.

c) Calculating the arithmetic mean through the following equation: $=\mathrm{K}$ (Yes) $\mathrm{x} 3+\mathrm{K}$ (To a certain extent) $\mathrm{x} 2+\mathrm{K}(\mathrm{No}) \mathrm{x} 1 / \mathrm{N}$. The statements are sorted in a descending order, where statements with the highest arithmetic mean come first.

d) Determining the standard deviation through calculating the dispersion coefficient in the frequencies of the three responses for each statement. This helped sort the statements in cases where more than one statement had the same arithmetic mean.

\section{The Results:}

\section{1-Characteristics of the community study:}

Table (3) Distribution of married minor girls according to social characteristics

\begin{tabular}{|c|c|c|c|c|}
\hline \multirow[t]{2}{*}{ Variables } & & \multirow[t]{2}{*}{ Responses } & \multicolumn{2}{|c|}{$\begin{array}{c}\text { Underage married girls } \\
(\mathrm{N}=87)\end{array}$} \\
\hline & & & $\mathrm{m}^{*}$ & S.D* \\
\hline \multirow{3}{*}{ age } & 1 & $\begin{array}{l}\text { The girl's age at } \\
\text { marriage }\end{array}$ & 14.245 & 0.657 \\
\hline & 2 & $\begin{array}{l}\text { The current age of the } \\
\text { girl }\end{array}$ & 18.987 & 1.254 \\
\hline & 3 & $\begin{array}{l}\text { Number of years of } \\
\text { marriage }\end{array}$ & 4.257 & 0.852 \\
\hline Variables & & Responses & 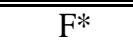 & $\overline{\%}$ \\
\hline \multirow{5}{*}{ Educational Status } & 1 & illiterate & 56 & 64.4 \\
\hline & 2 & You read and write & 18 & 20.7 \\
\hline & 3 & $\begin{array}{l}\text { She holds a primary } \\
\text { certificate }\end{array}$ & 13 & 14.9 \\
\hline & 4 & $\begin{array}{l}\text { She holds a preparatory } \\
\text { certificate }\end{array}$ & 0 & 0.00 \\
\hline & & Total & 87 & $\% 100$ \\
\hline \multirow{4}{*}{ Current marriage status } & 1 & Marriage exists & 67 & 777.0 \\
\hline & 2 & Divorced & 18 & 20.7 \\
\hline & 3 & $\overline{\text { Widow }}$ & 2 & 2.3 \\
\hline & & Total & 87 & $\% 100$ \\
\hline \multirow{4}{*}{$\begin{array}{l}\text { The number of children from } \\
\text { the marriage }\end{array}$} & 1 & Less than two children & $\overline{72}$ & 82.2 \\
\hline & 2 & $\begin{array}{l}\text { From } 2 \text { children to } 3 \\
\text { children }\end{array}$ & 9 & 10.3 \\
\hline & 3 & More than 3 children & 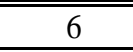 & 6.9 \\
\hline & & Total & 87 & $\% 100$ \\
\hline \multirow{3}{*}{ The status of work } & 1 & I do not work & 69 & 79.3 \\
\hline & & I Work & 18 & 20.7 \\
\hline & & Total & 87 & $\% 100$ \\
\hline
\end{tabular}




\begin{tabular}{|lr||}
\hline Egyptian Journal of Social Work (EJSW) & http://ejsw.journals.ekb.eg \\
ISSN: $2356-9204$ & Vol 13, Issue 1, January 2022 \\
\hline \hline
\end{tabular}

\begin{tabular}{|c|c|c|c|c|}
\hline \multirow[t]{2}{*}{ Variables } & \multirow{2}{*}{\multicolumn{2}{|c|}{ Responses }} & \multicolumn{2}{|c|}{$\begin{array}{l}\text { Underage married girls } \\
\qquad(\mathrm{N}=87)\end{array}$} \\
\hline & & & $\mathrm{m}^{*}$ & S.D* \\
\hline \multirow{4}{*}{ Family income level } & 1 & level Low income & 38 & 34.7 \\
\hline & 2 & level Average income & 47 & 54.0 \\
\hline & 3 & level High income & 2 & 2.3 \\
\hline & & Total & 87 & $\% 100$ \\
\hline \multirow{4}{*}{ number of family members } & 1 & Less than 3 people & 33 & 37.9 \\
\hline & 2 & From 3 to 4 persons & 46 & 52.9 \\
\hline & 3 & 5 or more persons & 8 & 9.2 \\
\hline & & Total & 87 & $\% 100$ \\
\hline
\end{tabular}

$(* \mathrm{~F}=$ Frequency $\& * \mathbf{m}=$ arithmetic mean $\& * \mathrm{~S} . \mathrm{D}=$ Standard Deviation)

The previous table regarding the characteristics of the population of the study shows that the average age of girls when getting married in the sample is approximately (14) years, with a standard deviation of (0.657). The current average age of the girl reached approximately (18) years, with a standard deviation of (1.254). The average number of years of marriage for a girl reached approximately (4) years, with a standard deviation of (0.852). The educational status of underage girls is as follows: the majority is illiterate (64.4\%), followed by those who can read and write (20.7\%), and followed by those who hold a primary certificate (14.9\%). Current marriage status for minor girls is as follows: marriage exists (77.0\%), followed by those who are divorced $(20.7 \%)$, and followed by those who are widows $(2.3 \%)$. As for the number of children from minor girls' marriages, it is as follows: less than two children (82.2\%), followed by those who have from 2 to 3 children (10.3\%), and followed by those who have more than 3 children (6.9\%). As for the employment status of underage girls, it is as follows: not employed (79.3\%) and followed by those who are employed (20.7\%). As for family income level for underage girls, it is as follows: Average income level (54.0\%), followed by those who have low income level (43.7\%), and followed by those who have high income level (2.3\%). Finally, there is the number of family members of minor girls, which is as follows: from 3 to 4 persons (52.9\%), followed by those who have less than 3 people (37.9\%), and followed by those who have 5 or more persons $(9.2 \%)$. 


\begin{tabular}{|lr||}
\hline Egyptian Journal of Social Work (EJSW) & http://ejsw.journals.ekb.eg \\
ISSN: $2356-9204$ & Vol 13, Issue 1, January 2022 \\
\hline
\end{tabular}

\section{2- Define the contributions of women's welfare associations to reduce the phenomenon of early marriage for girls}

Table (4): The contributions of women's welfare associations to reduce the phenomenon of early marriage for girls

\begin{tabular}{|c|c|c|c|c|c|c|c|c|c|}
\hline \multirow{3}{*}{$\begin{array}{l}\text { the Contributions of } \\
\text { women's welfare } \\
\text { associations }\end{array}$} & \multicolumn{6}{|c|}{ The beneficiaries $(\mathrm{N}=87)$} & \multirow{3}{*}{$\stackrel{*}{\Xi}$} & \multirow{3}{*}{ 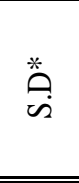 } & \multirow{3}{*}{ 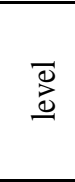 } \\
\hline & \multicolumn{2}{|c|}{ Yes } & \multicolumn{2}{|c|}{$\begin{array}{c}\text { To Some } \\
\text { extent }\end{array}$} & \multicolumn{2}{|c|}{ No } & & & \\
\hline & *F & $\%$ & *F & $\%$ & *F & $\%$ & & & \\
\hline $\begin{array}{l}\text { Help in knowing and } \\
\text { facing the problems } \\
\text { arising from early } \\
\text { marriage. }\end{array}$ & 53 & 60.9 & 19 & 21.8 & 15 & 17.2 & 2.4 & 2.01 & $\begin{array}{l}\text { High } \\
\text { level }\end{array}$ \\
\hline $\begin{array}{lr}\text { Directing } & \text { underage } \\
\text { girls to family medicine } \\
\text { centers to } r \text { treat } \\
\text { underage } & \text { Genital } \\
\text { problems } & \text { resulting } \\
\text { from early marriage. }\end{array}$ & 72 & 82.8 & 15 & 17.2 & 0 & 0.0 & 2.8 & 3.79 & $\begin{array}{l}\text { High } \\
\text { level }\end{array}$ \\
\hline $\begin{array}{lr}\text { Providing } & \text { family } \\
\text { counseling, to underage } \\
\text { girls, on how to } \\
\text { overcome } \\
\text { disputes family } \\
\text { husband. with the } \\
\end{array}$ & 61 & 70.1 & 12 & 13.8 & 14 & 16.1 & 2.5 & 2.77 & $\begin{array}{l}\text { High } \\
\text { level }\end{array}$ \\
\hline $\begin{array}{l}\text { Encouraging } \\
\text { community institutions } \\
\text { to satisfy the needs of } \\
\text { married minors. }\end{array}$ & 67 & 77.0 & 15 & 17.2 & 5 & 5.7 & 2.7 & 3.32 & $\begin{array}{l}\text { High } \\
\text { level }\end{array}$ \\
\hline $\begin{array}{l}\text { Helping the minor wife } \\
\text { to obtain her lost rights } \\
\text { as a result of her early } \\
\text { marriage. }\end{array}$ & 60 & 69.0 & 16 & 18.4 & 11 & 12.6 & 2.6 & 2.69 & $\begin{array}{l}\text { High } \\
\text { level }\end{array}$ \\
\hline $\begin{array}{l}\text { Providing financial and } \\
\text { in-kind assistance to the } \\
\text { minor girl to provide } \\
\text { for her essential needs. }\end{array}$ & 57 & 65.5 & 18 & 20.7 & 12 & 13.8 & 2.5 & 2.44 & $\begin{array}{l}\text { High } \\
\text { level }\end{array}$ \\
\hline $\begin{array}{c}\text { The general value of the } \\
\text { variable }\end{array}$ & 370 & 70.9 & 95 & 18.2 & 57 & 10.9 & 2.6 & Hig & level \\
\hline
\end{tabular}

Table (4) shows the index of the beneficiaries' perceptions of the contributions of women's welfare associations to reduce the phenomenon of early marriage for girls, with an average of (2.6), which is a high value. By analyzing the phrases, we find that the beneficiaries see that the most important contributions for the women's welfare associations to reduce the phenomenon of early marriage for girls are: directing underage girls to 


\begin{tabular}{|lr||}
\hline Egyptian Journal of Social Work (EJSW) & http://ejsw.journals.ekb.eg \\
ISSN: 2356-9204 & Vol 13, Issue 1, January 2022 \\
\hline \hline
\end{tabular}

medical family centers to treat underage girls suffering from genital problems resulting from early marriage, with an average of (2.8); followed by encouraging community institutions to satisfy the needs of married minors, with an average of (2.7); followed by helping the minor wife to obtain her lost rights as a result of her early marriage, with an average of (2.6); followed by providing financial and in-kind assistance to the minor girl to provide for her essential needs, with an average of (2.5) and a standard deviation of (2.44); followed by providing family counseling to underage girls on how to overcome family disputes with the husband, with an average of (2.5) and a standard deviation of (2.77), and finally help in knowing and facing the problems arising from early marriage, with an average of (2.4).

3- Proposals that contribute to helping women's welfare associations on facing the phenomenon of underage girl's marriage

Table (5): Proposals that contribute to helping women's welfare associations to face the phenomenon of underage girl's marriage

\begin{tabular}{|c|c|c|c|c|c|c|c|c|}
\hline \multirow{3}{*}{ Proposals } & \multicolumn{6}{|c|}{ The beneficiaries $(\mathrm{N}=87)$} & \multirow{3}{*}{$\stackrel{*}{\Xi}$} & \multirow{3}{*}{ 焕 } \\
\hline & \multicolumn{2}{|c|}{ Yes } & \multicolumn{2}{|c|}{$\begin{array}{c}\text { To Some } \\
\text { extent }\end{array}$} & \multicolumn{2}{|c|}{ No } & & \\
\hline & $* \mathrm{~F}$ & $\%$ & $* \mathrm{~F}$ & $\%$ & $* \mathrm{~F}$ & $\%$ & & \\
\hline $\begin{array}{l}\text { Holding seminars within the } \\
\text { community, to clarify the danger of } \\
\text { underage marriage. }\end{array}$ & 59 & 67.8 & 18 & 20.7 & 10 & 11.5 & 2.6 & 2.62 \\
\hline $\begin{array}{l}\text { Work to bridge the legal gaps that } \\
\text { allow circumventing the law by early } \\
\text { marriage through community dialogue. }\end{array}$ & 46 & 52.9 & 29 & 33.3 & 12 & 13.8 & 2.4 & 1.70 \\
\hline $\begin{array}{l}\text { Spreading } \\
\text { community members of the negative } \\
\text { health and social effects of early } \\
\text { marriage. }\end{array}$ & 73 & 83.9 & 7 & 8.0 & 7 & 8.0 & 2.8 & 3.81 \\
\hline $\begin{array}{l}\text { Supporting married girls by providing } \\
\text { them with reproductive health services, } \\
\text { and enabling them to earn a livelihood. }\end{array}$ & 79 & 90.8 & 8 & 9.2 & 0 & 0.0 & 2.9 & 4.34 \\
\hline $\begin{array}{l}\text { Creating mechanisms to provide for the } \\
\text { needs of underage girls to prevent them } \\
\text { from early marriage. }\end{array}$ & 81 & 93.1 & 6 & 6.9 & 0 & 0.0 & 2.9 & 4.51 \\
\hline $\begin{array}{l}\text { Providing the needs of underage girls to } \\
\text { reduce school dropout. }\end{array}$ & 71 & 81.6 & 12 & 13.8 & 4 & 4.6 & 2.6 & 3.65 \\
\hline
\end{tabular}

Table (5) shows the proposals that contribute to helping women's welfare associations to face the phenomenon of underage girl's marriage. By analyzing the phrases, we find that the beneficiaries see that the most important proposals that contribute to helping women's welfare associations 
to face the phenomenon of underage girl's marriage are: supporting married girls by providing them with reproductive health services and enabling them to earn a livelihood, with an average of (2.9) and a standard deviation of (4.34); followed by creating mechanisms to provide for the needs of underage girls to prevent them from early marriage, with an average of (2.9) and a standard deviation of (4.51); followed by spreading awareness among community members of the negative health and social effects of early marriage, with an average of (2.8); followed by holding seminars within the community to clarify the danger of underage marriage, with an average of (2.6) and a standard deviation of (2.62); followed by providing the needs of underage girls to reduce school dropout, with an average of (2.6) and a standard deviation of (3.65); and finally working to bridge the legal gaps that allow circumventing the law by early marriage through community dialogue, with an average of (2.4).

\section{The study hypothesis test:}

The first hypothesis test: "There is a statistically significant relationship at the level of significance $(0.05 \geq \alpha)$ between early marriage for girls and their social characteristics in terms of family income level, education, work, number of family members". This hypothesis could be confirmed by using the simple correlation coefficient "Pearson" as follows:

Table (6): Factor Pearson correlation to determine the relationship between the marriage of underage girls and some social variables

\begin{tabular}{|c|c|c|}
\hline \multirow{3}{*}{ Social variables } & \multicolumn{2}{|c|}{ Marriage of underage girls } \\
\hline & \multicolumn{2}{|c|}{ Correlations } \\
\hline & Pearson Correlation & Sig. (2-tailed) \\
\hline Family income level & $-0.751 *$ & 0.05 \\
\hline Education & $-0.703 *$ & 0.05 \\
\hline work & $-0.641 *$ & 0.05 \\
\hline " number of family members & 0.689* & 0.05 \\
\hline
\end{tabular}

*A significant function $(0.05 \geq \alpha) \quad \& * *$ A significant function $(0.01 \geq \alpha)$

Table (6) shows the relationship between early marriage for girls and their social characteristics in terms of family income level, education, work, number of family members, which is as follows:

As for the relationship between family income level and marriage of minor girls, the value of the correlation coefficient was equal to $(-0.751)$, which is negative, so it becomes clear that "there is a strong statistically significant inverse relationship at a significant level $(0.05 \geq \alpha)$ between marriage of underage girls and family income level". This indicates that the lower the family income level, the higher the marriage rates for underage girls. 
With regard to the relationship between education and marriage of underage girls, the value of the correlation coefficient was equal to $(-0.703)$, which is negative, so it becomes clear that "there is a strong statistically significant inverse relationship at a significant level $(0.05 \geq \alpha)$ between marriage of underage girls and education". This indicates that the lower the level of education, the higher the marriage rates for underage girls.

As for the relationship between work and marriage of underage girls, the value of the correlation coefficient was equal to $(-0.641)$, which is negative, so it becomes clear that "there is a strong statistically significant inverse relationship at a significant level $(0.05 \geq \alpha)$ between marriage of underage girls and work". This indicates that the fewer job opportunities, the higher the marriage rates for underage girls.

With regard to the relationship between the number of family members and the marriage of underage girls, the value of the correlation coefficient was equal to (0.689), which is positive, so it is clear that "there is a strong statistically significant direct relationship at a significant level $(0.05 \geq \alpha)$ between marriage of underage girls and the number of family members". This indicates that the greater the number of family members, the higher the marriage rates for underage girls.

The second hypothesis test: "There are statistically significant differences at the level of significance $(0.05 \geq \alpha)$ between underage girls and some social variables (e.g. education, age, work, number of family members, family income level)". This hypothesis could be confirmed by using the simple correlation coefficient "Pearson" as follows:

Table (7) shows the differences between underage girls and some social variables using one-way ANOVA

\begin{tabular}{|c|c|c|c|c|c|c|c|}
\hline variable & $\begin{array}{c}\text { Source of } \\
\text { contrast }\end{array}$ & $\begin{array}{l}\text { Sum of } \\
\text { squares }\end{array}$ & $\begin{array}{c}\text { Average } \\
\text { of } \\
\text { squares }\end{array}$ & d.f & $\begin{array}{l}\text { Average } \\
\text { squares }\end{array}$ & $\mathrm{f}$ & Sig \\
\hline \multirow{3}{*}{ education } & $\begin{array}{l}\text { Between } \\
\text { Groups }\end{array}$ & 6314.521 & 2703.552 & 3 & 2.336 & \multirow{3}{*}{$\begin{array}{c}18.69 \\
0\end{array}$} & \multirow{3}{*}{$* 0.05$} \\
\hline & $\begin{array}{l}\text { Within } \\
\text { Groups }\end{array}$ & 1228.538 & 9830.982 & 83 & \multirow[t]{2}{*}{0.125} & & \\
\hline & total & 7543.059 & & 86 & & & \\
\hline \multirow{3}{*}{ age } & $\begin{array}{l}\text { Between } \\
\text { Groups }\end{array}$ & 13.369 & 2.886 & 3 & 4.632 & \multirow{3}{*}{0.898} & \multirow{3}{*}{1.965} \\
\hline & $\begin{array}{l}\text { Within } \\
\text { Groups }\end{array}$ & 8.137 & 1.578 & 83 & \multirow[b]{2}{*}{5.157} & & \\
\hline & total & 21.506 & & 86 & & & \\
\hline
\end{tabular}




\begin{tabular}{|lr||}
\hline \hline Egyptian Journal of Social Work (EJSW) & http://ejsw.journals.ekb.eg \\
ISSN: 2356-9204 & Vol 13, Issue 1, January 2022 \\
\hline \hline
\end{tabular}

\begin{tabular}{|c|c|c|c|c|c|c|c|}
\hline variable & $\begin{array}{c}\text { Source of } \\
\text { contrast }\end{array}$ & $\begin{array}{l}\text { Sum of } \\
\text { squares }\end{array}$ & $\begin{array}{c}\text { Average } \\
\text { of } \\
\text { squares }\end{array}$ & d.f & $\begin{array}{l}\text { Average } \\
\text { squares }\end{array}$ & $\mathrm{f}$ & Sig \\
\hline \multirow{3}{*}{ work } & $\begin{array}{l}\text { Between } \\
\text { Groups }\end{array}$ & 72.225 & 2.596 & 3 & 27.822 & \multirow{3}{*}{5.224} & \multirow{3}{*}{$* 0.05$} \\
\hline & $\begin{array}{l}\text { Within } \\
\text { Groups } \\
\end{array}$ & 4.628 & 0.869 & 83 & \multirow[t]{2}{*}{5.326} & & \\
\hline & total & $7 \overline{76.853}$ & & 86 & & & \\
\hline \multirow{3}{*}{$\begin{array}{l}\text { number of } \\
\text { family } \\
\text { members }\end{array}$} & $\begin{array}{l}\text { Between } \\
\text { Groups }\end{array}$ & 360.106 & 3.102 & 3 & 116.088 & \multirow{3}{*}{9.243} & \multirow{3}{*}{$* 0.05$} \\
\hline & $\begin{array}{l}\text { Within } \\
\text { Groups }\end{array}$ & 12.02 & 0.957 & 83 & 12.560 & & \\
\hline & total & 372.126 & & 86 & & & \\
\hline \multirow{3}{*}{$\begin{array}{c}\text { Family } \\
\text { income } \\
\text { level }\end{array}$} & $\begin{array}{l}\text { Between } \\
\text { Groups }\end{array}$ & 9679.137 & 233.568 & 3 & 41.440 & \multirow{3}{*}{4.099} & \multirow{3}{*}{$* 0.05$} \\
\hline & $\begin{array}{l}\text { Within } \\
\text { Groups } \\
\end{array}$ & 1047.338 & 103.587 & 83 & \multirow[t]{2}{*}{10.111} & & \\
\hline & total & 10726.475 & & 86 & & & \\
\hline
\end{tabular}

*A significant function $(0.05 \geq \alpha) \quad \& * *$ A significant function $(0.01 \geq \alpha)$

Table (7) shows the differences between underage girls and some social variables in terms of education, age, work, number of family members, and family income level, and it is as follows: as for the differences between married minor girls and the level of education, the $(\mathrm{F})$ value calculated was $(18,690)$, which is greater than the theoretical value of $(F)$, which was equal to $(2.29,2.18)$ at a degree of freedom $(3,83)$ and a significant level of $(0.05 \geq \alpha)$. Thus, it becomes clear that there are statistically significant differences at a significant level $(0.05 \geq \alpha)$ among married minor girls on the educational level.

As for the differences between married minor girls and age, the $(\mathrm{F})$ value calculated was (1.965), which is smaller than the theoretical value of $(\mathrm{F})$, which was equal to $(2.29,2.18)$ at a degree of freedom $(3,83)$ and a significant level of $(0.05 \geq \alpha)$. Therefore, there are statistically significant differences at a significant level $(0.05 \geq \alpha)$ among married minor girls in age.

As for the differences between married minor girls and work, the $(\mathrm{F})$ value calculated was (5.224), which is greater than the theoretical value of $(F)$, which was equal to $(2.29,2.18)$, at a degree of freedom $(3,83)$ and a significant level of $(0.05 \geq \alpha)$. Hence, it becomes clear that there are statistically significant differences at a significant level $(0.05 \geq \alpha)$ among married minor girls in work. 
As for the differences between married minor girls and the number of family members, the $(\mathrm{F})$ value calculated was (9.243), which is greater than the theoretical value of $(F)$, which was equal to $(2.29,2.18)$ at a degree of freedom $(3,83)$ and a significant level of $(0.05 \geq \alpha)$. Consequently, there are statistically significant differences at a significant level $(0.05 \geq \alpha)$ among married minor girls in the number of family members.

As for the differences between married minor girls and family income level, the $(\mathrm{F})$ value calculated was (4.099), which is greater than the theoretical value of $(F)$, which was equal to $(2.29,2.18)$ at a degree of freedom $(3,83)$ and a significant level of $(0.05 \geq \alpha)$. Thus, it becomes clear that there are statistically significant differences at a significant level $(0.05 \geq \alpha)$ among married minor girls concerning the family income level.

\section{Discussion of the results of the study:}

- The results of the study showed that the social characteristics of underage girls were: the average of their ages at marriage is approximately (14) years, the average number of years of marriage for a girl approximately reached (4) years, most of the girls are illiterate, most of them are currently married, the number of children from the marriage of minor girls who are still married is less than two children, most of them do not work, their income level is average, and the number of family members for minor girls is from 3 to 4 persons." These results are consistent with a study (Muthengi, 2010), which confirmed that early marriage, defined as marriage of girls below the age of 18 years, is often driven by poverty and supported by social norms that foster gender inequalities. Moreover, they are also consistent with the study (Kimball, 2011), which finds that female education has negative relationship with child marriage rates. Furthermore, the results are consistent with the study (Adjei, 2015), which illustrates that negative practices, such as early marriage and the challenges of underdevelopment and poverty, have served as constraints to women's development."

- The results of the study confirmed the contributions of women's welfare associations to reduce the phenomenon of early marriage for girls are: directing underage girls to medical family centers to treat underage genital problems resulting from early marriage and encouraging community institutions to satisfy the needs of married minors. "This is consistent with what the "general systems theory" has demonstrated. The contributions of women's welfare societies can be interpreted according to this study at the level of macro and micro (societies and interactions) as a structure that consists of buildings and sub-formats, which are performing important functions as it is affected by the rest of society and its systems (dependent on some of them and complement each other to contribute to facing the four 
problems: adaptation, goal achievement, integration, and stress reduction".

- The results of the study concluded that proposals contribute to helping women's welfare associations to face the phenomenon of underage girl's marriage through: supporting married girls by providing them with reproductive health services, enabling them to earn a livelihood, creating mechanisms to provide for the needs of underage girls to prevent them from early marriage. "This is consistent with a study (Adjei, 2015), where recommendations are made for advocating the eradication of early marriage practices, improving girl-child educational scholarships, and improving skilled-based programs for women. More importantly, greater enforcement of the law should be placed on distasteful traditional practices that create harmful outcomes for women's development".

- The results of the study confirmed the existence of a statistically significant correlation between marriage of underage girls and their social characteristics in terms of income, education, and work." This is consistent with a study (Muthengi, 2010), and the results show that the association between the timing of marriage and economic resources is partially mediated by education, and primary school completion is strongly associated with increased access to cash income and household wealth".

- The study also confirmed that there are statistically significant differences between underage married girls according to the difference in some social variables such as education, work, number of family members, and income. There are no differences between them according to the variable of age. "This is consistent with a study (Muthengi, 2010), where the results show that the association between the timing of marriage and economic resources is partially mediated by education, and primary school completion is strongly associated with increased access to cash income and household wealth". "This is also consistent with a study (Adjei, 2015), where recommendations are made based on the findings collected, and these include advocating the eradication of early marriage practices, improving girl-child educational scholarships, and improving skilled-based programs for women".

The study's recommendations are to activate the contributions of women welfare associations to limit the phenomenon of child marriage in the light of Social Work and the way society is organized:

1- Supporting married girls by providing them with reproductive health services.

2- Creating mechanisms to provide for the needs of underage girls to prevent them from early marriage. 
3- Spreading awareness among community members of the negative health and social effects of early marriage.

4- Holding seminars within the community to clarify the danger of underage marriage.

5- Providing the educational needs of underage girls to reduce school dropout.

6- Working to bridge the legal gaps that allow circumventing the law by early marriage through community dialogue.

\section{References:}

Adjei, Doris (2015). The cycle of poverty and early marriage among women in Ghana (A case study of Kassena-Nankana), M.A. Degree, University of Northern British Columbia (Canada), Canada.

Bakhtibekova, Zulfiya (2014). Early girls' marriage in Tajikistan: causes and continuity, Ph.D. Degree, University of Exeter (United Kingdom), England.

Boender, Carol (2015). Child marriage and early and forced marriage, CARE Globalism and Kendeda Fund, Brussels, Belgium.

Central Agency for Public Mobilization and Statistics (2017). Population, Housing and Establishments Census, Arab Republic of Egypt.

Gaston, C. M.and Misunas, C.C., (2019). Child marriage among boys: a global overview of available data, Journal Vulnerable Children and Youth Studies an International Interdisciplinary Journal for Research, Policy and Care, Vol (14).

Etziono, Amitia (1964). Modern Organization, Prentice- Hall, Inc, New Jersey, USA.

Hearn, G.(1969). The General Systems Approach: Contribution Toward an Holistic Conception of Social Work, New York: Council of Social Work Education.

Kimball, Katherine (2011). Till death do us part: Explaining the roots of child marriage, M.P.P. Degree, Georgetown University, United States -- District of Columbia.

Lackovich-Van Gorp, Ashley N.(2014). Positive deviance and child marriage by abduction in the Sidama Zone of Ethiopia, Ph.D. Degree, Antioch University, United States - Ohio.

Liu, Sheng (2013). Mother's Early Age of Marriage Predicts Children Malaria Risk in the Peruvian Amazon, M.A. Degree, Duke University, United States -- North Carolina.

Muthengi, Eunice Ndunge (2010). Early Marriage and Early Childbearing in Ethiopia: Determinants and Consequences, Ph.D. Degree, University of California, Los Angeles, United States - California.

Nour, NM (2009). Child Marriage: a silent health and human rights issue, Reviews in Obstetrics and Gynecology. 2 (1): 51-56. PMID

Parsons, Jennifer., Edmeades, Jeffrey., Aslihan, Kes., Petroni, Suzanne., Sexton, Maggie.,and Wodon, Quentin. (2015). Economic Impacts of Child Marriage: A Review of the Literature, The Review of Faith \& International Affairs. 13 (3):

Rodway, M. R.(1986): Systems Theory. In F. J. Turner (Ed.). Social work Treatment. New York: The Free Press.

Sagade, Jaya Vishnu (2002). Socio -legal and human rights dimensions of child marriage in India, S.J.D. Degree, University of Toronto (Canada), Canada.

Sen Nag, Oishimaya (2017). Child Marriage - Rationale, Historical Views, and Consequences, on April 25, in Society, World Atlas.

Sharon K. H. and Susan K. L.(2005). Explaining Teen Childbearing and Cohabitation: Community Embeddedness and Primary Ties, Family Relations, Vol. 54, No. 5, Families and Communities (Dec., 2005). 


\begin{tabular}{|lr||}
\hline Egyptian Journal of Social Work (EJSW) & http://ejsw.journals.ekb.eg \\
ISSN: 2356-9204 & Vol 13, Issue 1, January 2022 \\
\hline \hline
\end{tabular}

UNICEF, (2000). program Child marriage, United Nations International Children's Emergency Fund, New York, United States.

United Nations (1964). Agreement on Consent to Marriage, Minimum Age for Marriage, and Registration of Marriage Contracts, Offered for signature, ratification and accession under United Nations General Assembly Resolution 1763 A (17-d) of 7 November 1964 Date of entry into force: 9 December 1964, in accordance with the provisions of Article 6

Waters, Amy Jean Lopez (2019). When "Girls Marry Without Having a Legitimate Age": Gender, Ethnicity, and Youth in Historicizing Child Marriage in Chiapas, Mexico, M.A. Degree, University of California, Davis, United States - California.

Zahran, Hamdiya (2000). The role of Egyptian women in production within the framework of comprehensive national development, National Population Council, Cairo. 
